ISSN 1392-3196 / e-ISSN 2335-8947

Zemdirbyste-Agriculture, vol. 108, No. 1 (2021), p. 43-50

DOI 10.13080/z-a.2021.108.006

\title{
Improving nutritional value of products with flour of the hulless barley cultivar 'Kornelija' as an ingredient
}

\author{
Vita STERNA ${ }^{1}$, Mara BLEIDERE ${ }^{1}$, Martins SABOVICS ${ }^{2}$, Alberts AUZINS ${ }^{1}$, Ieva LEIMANE ${ }^{1}$, \\ Agnese KRIEVINA ${ }^{1}$ \\ ${ }^{1}$ Institute of Agricultural Resources and Economics "Dižzemes" \\ Dižstende, 3258 Talsi distr., Latvia \\ E- mail: vita.sterna@arei.lv \\ ${ }^{2}$ Latvia University of Life Sciences and Technologies \\ Lielā 2, 3001 Jelgava, Latvia
}

\begin{abstract}
Hulless barley (Hordeum vulgare L.) potential for various end uses is attracting increased attention, because its ingredient health benefits make this cereal an excellent raw material for functional food production. Hulless barley also offers economic benefits for food industry compared to hulled barley as well as opportunities to farmers to diversify cereal growing. It allows improvement of the nutritional value of the existing grain products and evaluation of new products. Despite these advantages, hulless barley is not widely common in food industries of European countries.

The aim of the study was to determine the possibilities to develop products with increased nutritional value that contain the grains of hulless barley cultivar 'Kornelija' as a raw material by exploring the use of extrusion and adding the hulless barley flour to pasta and extruded pea flakes mix. According to the obtained results, the extrusion process had a minor effect on the protein and $\beta$-glucans content of extruded hulless barley flour, while the sum of essential amino acids was determined higher $\left(55.5 \mathrm{~g} \mathrm{~kg}^{-1}\right)$ in comparison with the untreated samples $\left(51.4 \mathrm{~g} \mathrm{~kg}^{-1}\right)$ with significantly higher content of tyrozine and lysine. It was also found that by replacing $20 \%$ of wheat flour with hulless barley 'Kornelija' flour to improve the nutritional value of pasta, the content of protein and dietary fibre increased. The combination of extruded pea flakes with hulless barley flour also improved the nutritional value of the pea-barley semi-finished mix allowing an increase in protein and dietary fibre content.
\end{abstract}

Key words: extrusion, functional food, hulless barley, nutritional value, pasta.

\section{Introduction}

Barley (Hordeum vulgare L.) is the second most important cereal in the European Union for feed and food production after wheat (Eurostat, 2020). Hulless barley cultivars compared to hulled ones have increased nutritional value, especially higher content of protein (Ehrenbergerova et al., 2003), $\beta$-glucans and soluble dietary fibre (Baik, Ullrich, 2008; Bleidere et al., 2013; Sterna et al., 2017), which allow their use as an excellent raw material for functional food production. Higher $\beta$ glucans content of hulless barley compared to hulled barley and other cereals serves as a beneficial chemical compound in the diet of humans and has a positive effect on human health (Ames et al., 2006; Alminger, EklundJonsson, 2008). Also, technologically, hulless barley whole grain or flour is a very good ingredient, because it is free from hulls and needs no dehulling process. Hulless barley has been recognized as more suitable and economical for the food industry than hulled barley (Newman, Newman,
2008; Arendt, Zannini, 2013). Growing hulless barley is highly popular in Japan, Australia, Canada and USA. In Europe, although available on the market, hulless barley cultivars have not gained high popularity either for forage or for food.

With rising healthcare costs, average life expectancy and the desire to have a better quality of life, the public has been increasingly concerned about health and seeking ways to become healthier by paying more attention to the lifestyle and diet (Martirosyan, Singh, 2015; Vicentini et al., 2016). The increasing awareness about a strong relationship between diet and human health has considerably changed food preferences in developed countries with functional food products being an excellent food option (Díaz et al., 2020). The size of the global functional foods market was estimated at 136.74 billion EUR (161.49 billion USD) in 2018 and is expected to reach 212 billion EUR ( 250 billion USD)

Please use the following format when citing the article:

Sterna V., Bleidere M., Sabovics M., Auzins A., Leimane I., Krievina A. 2021. Improving nutritional value of products with flour of the hulless barley cultivar 'Kornelija' as an ingredient. Zemdirbyste-Agriculture, 108 (1): 43-50. DOI 10.13080/z-a.2021.108.006 
by 2024. According to the Grand View Research (2020), increasing demand for nutritional content in food items is anticipated to drive the growth, already now the sales of food products with health and wellness claims are growing faster than those of conventional food products (Nunes et al., 2020). "Naturally functional", "fragmentation" (of consumers beliefs), "snackification" and "sustainability" are four mega trends in food, nutrition and health that should be must-do for all companies, in addition to "digestive wellness", "plant-based" and "protein" named among the 10 key trends in food, nutrition and health for 2020, according to the New Nutrition Business (2019). Cereals offer unlimited opportunities for the production of functional foods.

The consumption of whole grain products is recommended in many world popular diets. The Mediterranean diet pyramid recommends the consumption of one or two servings of cereals at each main meal, preferably whole grain. The recommended daily consumption of whole grain products in the USA is set at least at $85 \mathrm{~g}$ per day for adults and $42 \mathrm{~g}$ per day for

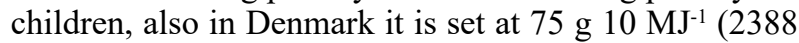
kcal) per day (Ruggiero et al., 2019). Hulless barley provides a significant advantage to food manufacturers, enabling the development and production of functional foods (Arendt, Zannini, 2013). This provides a possibility to produce food for people, who need specific diets because of severe diseases such as diabetes. Inclusion of hulless barley grains in human nutrition is particularly valuable for diabetic patients because of its ability to lower glycemic index (Jenkins et al., 2002; Meija et al., 2019). An elevated total fibre and soluble fibre $\beta$-glucans content in a diet reduces cholesterol levels in blood (Havrlentova et al., 2011), which improves cardiovascular disease prevention (Mitsou et al., 2010).

Hulless barley development and potential for various end uses is attracting growing attention both in Latvia and other countries. Over the last decade, several hulless barley cultivars have been developed: 'Irbe' and 'Kornelija' in Latvia and 'Pihl' in Norway (Sturite et al., 2019). Overall, the yield potential of hulless barley is usually lower than that of hulled barley. Research results confirmed that the yield potential of hulless barley 'Kornelija' is moderate; however, the agronomic advantages shown under different growing conditions are its earliness and coarse grains (Bleidere et al., 2013; Tamm et al., 2015). Grain threshability of this cultivar is high $-97 \%$ to $100 \%$ of hulls are removed during harvesting.

The grains of hulless barley 'Kornelija' have very good potential to be used as an ingredient for the growing demand in wellness and functional food market. The significant advantage of grains is that it has both high protein and $\beta$-glucans content; thus, its grains and flour as ingredients allow boosting protein and $\beta$-glucans content in a product simultaneously, which other cereals (especially wheat) lack.

A recent study (unpublished) carried out by Latvian Institute of Agricultural Resources and Economics indicates that hulless barley 'Kornelija' grains are also a cost-efficient raw material (ingredient). According to this study, the estimated market price of 'Kornelija' grains is close to the market price of wheat. Therefore, it is possible to purchase an ingredient with markedly better properties than wheat, which costs almost the same. It also means that adding hulless barley 'Kornelija' grains or flour as ingredient should not increase the cost of a product.

It is well known that the preparation of traditional products as pearl and groats is time consuming. Therefore, new technologies and products (for example, semi-finished food) have been developed to diversify diet, increase nutritional value of products and make their preparation easier. Extrusion is one of the methods of processing that may affect the nature of grain or seed components, its physical, chemical and nutritional properties (Diaz et al., 2006); however, it has been found to have minor effect on protein and fat content of peas, faba beans and soya (Strauta, Muižniece-Brasava, 2016; Kudlinskienè et al., 2020).

High-temperature short-time (HTST) extrusion technology has become popular in preparing snacks and breakfast cereals of starchy base products (Nikmaram et al., 2017). Overall, extruded products are well known in the food industry: breakfast cereals or biscuits made of corn, snacks made of peas or faba beans, most often. But there has not been much investigation on the extrusion of buckwheat or barley. The quality and nutritional value of the extruded products could be affected not only by the species of grains but also by a cultivar, its chemical composition and physical traits.

Also, studies showed that bread enriched with barley grains has significantly higher dietary fibre content, including $\beta$-glucans, higher protein and fat content. By replacing wheat flour with hulless barley grains or flour up to $30 \%$ and $40 \%$, it is possible to obtain bread with good porosity (Kinner et al., 2011; Rieder et al., 2012; Sterna et al., 2019).

The aim of the study was to determine the possibilities to develop new products with increased nutritional value that contain the hulless barley cultivar 'Kornelija' grains as a raw material by exploring the use of extrusion and adding the hulless barley flour to pasta and extruded pea flakes mix.

\section{Materials and methods}

The research was conducted at the Institute of Agricultural Resources and Economics. The material used in the development of experimental products was flour of the hulless barley (Hordeum vulgare L.) cultivar 'Kornelija' from the grain harvest of 2018 grown at the Stende Research Centre (lat. 57.1412 ${ }^{\circ} \mathrm{N}$, long. $22.5367^{\circ} \mathrm{E}$ ).

Growing conditions. In 2018, May was warm and dry; such weather conditions lasted until mid-June. The amount of precipitation in May, June and July was only $28 \%$ to $40 \%$ of the average of long-term observations. The months of May and July were especially hot with the average daily air temperatures $2.4^{\circ} \mathrm{C}$ and $2.7^{\circ} \mathrm{C}$ above normal; such weather conditions promoted protein accumulation. Hulless barley was grown on the field area of 1 ha in the soil with the following parameters: organic matter $20 \mathrm{~g} \mathrm{~kg}^{-1}$, pH 5.9, $\mathrm{P}_{2} \mathrm{O}_{5} 188 \mathrm{mg} \mathrm{kg}^{-1}$ and K O $150 \mathrm{mg} \mathrm{kg}^{-1}$. Complex fertilizer NPK 15-15-15 + $10 \mathrm{~S}$ was applied before sowing at a rate of $535 \mathrm{~kg} \mathrm{ha}^{-1}$ providing the amounts of nutrients $80 \mathrm{~kg} \mathrm{ha}^{-1}$ nitrogen (N), $80 \mathrm{~kg}^{-1}$ phosphorus (P), $80 \mathrm{~kg}^{-1}$ potassium (K) and $54 \mathrm{~kg} \mathrm{ha}^{-1}$ sulphur (S). Harvested grain was cleaned by a cleaner PETKUS (Germany) with rectangular hole sieve $(2.2 \times 20 \mathrm{~mm})$. Test weight, protein, starch and $\beta$-glucans content of the grains were determined using an automatic grain analyser Infratec NOVA (FOSS, Denmark). 
The chemical composition of flour of hulless barley 'Kornelija' is summarized in Table 1.

Table 1. The chemical composition of hulless barley 'Kornelija' flour

\begin{tabular}{lc}
\hline \multicolumn{1}{c}{ Nutrients } & Mean $\pm \mathrm{SD}$ \\
\hline Protein g $100 \mathrm{~g}^{-1}$ & $20.84 \pm 0.20$ \\
$\beta$-glucans g $100 \mathrm{~g}^{-1}$ & $6.15 \pm 0.02$ \\
Dietary fibre g $100 \mathrm{~g}^{-1}$ & $17.40 \pm 2.50$ \\
Starch g $100 \mathrm{~g}^{-1}$ & $47.91 \pm 0.05$ \\
Total sugars g $100 \mathrm{~g}^{-1}$ & $1.88 \pm 0.35$ \\
Fat g $100 \mathrm{~g}^{-1}$ & $2.11 \pm 0.10$ \\
$\sum$ EAA g kg-1 & $51.40 \pm 0.39$ \\
\hline
\end{tabular}

Note. $\sum$ EAA - the sum of essential amino acids; values are the mean of 4 samples and respective standard deviations.

The chemical analyses of flour and experimental products of the hulless barley for protein, fat, starch and $\beta$-glucans content were carried out at the Laboratory of Cereal Technology and Agricultural Chemistry of the Institute of Agricultural Resources and Economics. Collected samples of experimental products, three subsamples of each batch for chemical analyses, were dried at $60^{\circ} \mathrm{C}$ temperature, ground in mill with a $1.0 \mathrm{~mm}$ sieve. Protein content was determined by the Kjeldahl method, and conversion factor 6.25 was used to convert total $\mathrm{N}$ to crude protein. Fat was extracted with petroleum ether (boiling range of $40-60^{\circ} \mathrm{C}$ ) by the Soxhlet extraction ((EPA 3540C) method and determined gravimetrically. Content of $\beta$-glucans was determined according to the ICC Standard Method No. 168 (Amyloglucosidase method) for assessing mixed-linkage $\beta$-glucans by using (Assay Kits Megazyme Ltd.). Content of starch determined by LVS EN ISO 10520:2001 (Native starch - Determination of starch content - Ewers polarimetric method). Amino acids profile, total dietary fibre content and total sugars content and profile were tested in the accredited laboratory J.S. Hamilton Baltic. Dietary fibre was determined by AOAC 991.43:1994 method, total sugars - by PB-79/HPLC ed. V18.05.2017, proteinogenic amino acid profile - by PB-53/HPLC ed. II of 30.12.2008 methods. The sum of essential amino acids ( $\sum$ EAA) was calculated as a total amount of histidine, tyrosine, valine, methionine, cysteine, isoleucine, leucine, phenylalanine and lysine.

Extrusion of the hulless barley flour was carried out at the Faculty of Food Technology of Latvia University of Life Sciences and Technologies using double-screw equipment DSE32 (Shengrun Machinery Co. Ltd, China). Screw speed was $30 \mathrm{~Hz}$, the speed of the movement of extrusion material was $10 \mathrm{~Hz}$ and humidity level - 19-20\%.

The $1^{\text {st }}$ step - five temperature modes were selected $\left({ }^{\circ} \mathrm{C}\right)$ : 1) 50/80/125/170, 2) 55/90/125/150, 3) $55 / 90 / 125 / 160$, 4) 55/90/125/170 and 5) 55/90/125/180. After the extrusion, three subsamples from each batch of the extruded product were tested for protein, starch and $\beta$-glucans content to evaluate the impact of temperature on the chemical composition.

The $2^{\text {nd }}$ step - three milling rates (coarse, medium and fine) were selected for the extrusion at the optimal temperature mode $-55 / 90 / 125 / 180^{\circ} \mathrm{C}$, and the chemical composition of the obtained extruded products were evaluated for protein, starch and $\beta$-glucans content
Profiles of amino acids and sugars and amount of total dietary fibre were determined and compared with the raw material (untreated flour of 'Kornelija' grains) traits.

Pasta preparation was carried out at ColorPasta (Latvia). The $1^{\text {st }}$ step - preparation of dough containing hulless barley 'Kornelija' (K) flour. Wheat flour type 812 (Rigas Dzirnavnieks Ltd., Latvia) was used as the main raw material. Its chemical composition was: protein $13.4 \%$, fat $1.3 \%$, starch $47.9 \%$ and $\beta$-glucans $0.6 \%$. Spinach and parsley $80 \mathrm{~g}$ of each were used for the preparation of a puree with $60 \mathrm{~g}$ of water added and blended. The following combinations were prepared: 1) $80 \mathrm{~g}$ wheat $(\mathrm{W})$ flour $+40 \mathrm{~g}$ puree (control); 2) $64 \mathrm{~g}$ wheat flour $+16 \mathrm{~g}$ hulless barley flour $+40 \mathrm{~g}$ puree $(80 \mathrm{~W} / 20$ $\mathrm{K})$; 3) $56 \mathrm{~g}$ wheat flour $+24 \mathrm{~g}$ hulless barley flour $+40 \mathrm{~g}$ puree $(70 \mathrm{~W} / 30 \mathrm{~K})$ and 4$) 48 \mathrm{~g}$ wheat flour $+32 \mathrm{~g}$ hulless barley flour $+40 \mathrm{~g}$ puree $(60 \mathrm{~W} / 40 \mathrm{~K})$. Dough for pasta was initially kneaded in a stainless-steel bowl, kneading completed on an oak surface, wrapped in a film and rested for $1 \mathrm{~h}$ at $6^{\circ} \mathrm{C}$ temperature. Afterwards slices were formed and dried at a working environment temperature of $15^{\circ} \mathrm{C}$. The $2^{\text {nd }}$ step - evaluation of chemical composition of pasta at optimal flour combination. Protein, starch and $\beta$-glucans content and the profile of amino acids were determined, and nutritional value was calculated.

Preparation of mixed semi-finished products. In one of the experiments, dough was prepared by mixing pea flakes with water and adding salt, then the scones were formed from the dough and fried. The combination of pea (P) flakes with hulless barley 'Kornelija' (K) flour was investigated to improve the nutritional value, to increase and diversify dietary fibre content of the prepared product, while simultaneously decreasing the amount of carbohydrates. Extruded pea flakes Veggy Crush BIO (Milzu! Ltd., Latvia) were used as a control. Chemical composition of the control material was protein $17.1 \%$, fat $1.5 \%$, carbohydrates $67.3 \%$ and dietary fibre $8.4 \%$. The following combinations were prepared: 1$)$ $100 \%$ extruded pea (P) flakes (control); 2) $80 \mathrm{~g}$ extruded pea flakes and $20 \mathrm{~g}$ hulless barley 'Kornelija' (K) flour $(80 \mathrm{P} / 20 \mathrm{~K})$; 3) $70 \mathrm{~g}$ extruded pea flakes and $30 \mathrm{~g}$ hulless barley flour $(70 \mathrm{P} / 30 \mathrm{~K})$; 4) $50 \mathrm{~g}$ extruded pea flakes and $50 \mathrm{~g}$ hulless barley flour $(50 \mathrm{P} / 50 \mathrm{~K})$; to all combinations $1.5 \mathrm{~g}$ salt was added. The dough was prepared by mixing flakes (or flakes and flour mixes) with water $1: 2(\mathrm{~g} / \mathrm{g})$ allowing the dough to rest for $5 \mathrm{~min}$ to form scones and to fry $8-10 \mathrm{~min}$. Sensory characteristic and texture analysis of fried scones were tested by the experiment team.

Statistical analysis. The obtained results were statistically processed using methods of descriptive statistics (sample mean and standard deviation), comparison of untreated and extruded product was made by comparison of each amino acid values with software package SPSS, version 12 (SPSS Inc., USA). Statistical significance was declared at $p<0.05$.

\section{Results and discussion}

Chemical composition and nutrition value of extruded hulless barley 'Kornelija' flour. Comparison of protein, starch and $\beta$-glucans content after the extrusion in different regimes (results obtained in the $1^{\text {st }}$ step) is shown in Table 2 .

The chemical composition of untreated and extruded barley product (results obtained in the $2^{\text {nd }}$ step) is depicted in Table 3. 
Table 2. The chemical composition of hulless barley 'Kornelija' flour extruded at different temperatures

\begin{tabular}{|c|c|c|c|c|}
\hline & Moisture & Protein & Starch & $\beta$-glucans \\
\hline Temperature & \multicolumn{4}{|c|}{$\%$ (values are the mean of 3 samples and respective standard deviations) } \\
\hline $50 / 80 / 125 / 170^{\circ} \mathrm{C}$ & $11.80 \pm 0.05$ & $20.60 \pm 0.21$ & $51.26 \pm 0.52$ & $5.92 \pm 0.02$ \\
\hline $55 / 90 / 125 / 150^{\circ} \mathrm{C}$ & $11.12 \pm 0.05$ & $20.33 \pm 0.20$ & $50.85 \pm 0.51$ & $5.99 \pm 0.02$ \\
\hline $55 / 90 / 125 / 160^{\circ} \mathrm{C}$ & $11.00 \pm 0.05$ & $19.98 \pm 0.20$ & $51.45 \pm 0.53$ & $6.15 \pm 0.02$ \\
\hline $55 / 90 / 125 / 170^{\circ} \mathrm{C}$ & $8.32 \pm 0.04$ & $20.46 \pm 0.21$ & $49.99 \pm 0.50$ & $5.87 \pm 0.02$ \\
\hline $55 / 90 / 125 / 180^{\circ} \mathrm{C}$ & $8.80 \pm 0.04$ & $20.74 \pm 0.22$ & $49.81 \pm 0.50$ & $5.90 \pm 0.02$ \\
\hline \multicolumn{5}{|l|}{ Milling rates } \\
\hline Fine & $9.09 \pm 0.04$ & $20.08 \pm 0.20$ & $50.02 \pm 0.50$ & $4.83 \pm 0.02$ \\
\hline Medium & $9.00 \pm 0.04$ & $20.45 \pm 0.21$ & $49.32 \pm 0.50$ & $5.79 \pm 0.02$ \\
\hline Coarse & $8.90 \pm 0.04$ & $19.84 \pm 0.20$ & $51.03 \pm 0.51$ & $5.91 \pm 0.02$ \\
\hline
\end{tabular}

Table 3. The comparison of chemical composition of untreated flour and extruded product (at $55 / 90 / 125 / 180^{\circ} \mathrm{C}$ ) of hulless barley 'Kornelija' flour

\begin{tabular}{|c|c|c|c|c|c|}
\hline Nutrients & Untreated & Extruded & Nutrients & Untreated & Extruded \\
\hline Protein g $100 \mathrm{~g}^{-1}$ & $20.84 \pm 0.20$ & $20.24 \pm 0.20$ & Total sugars g $100 \mathrm{~g}^{-1}$ & $1.88 \pm 0.35$ & $2.20 \pm 0.35$ \\
\hline$\beta$-glucans g $100 \mathrm{~g}^{-1}$ & $6.15 \pm 0.02$ & $5.51 \pm 0.02$ & Glucose g $100 \mathrm{~g}^{-1}$ & $0.26 \pm 0.06$ & $0.20 \pm 0.03$ \\
\hline Dietary fibre g $100 \mathrm{~g}^{-1}$ & $17.40 \pm 2.50$ & $14.60 \pm 2.30$ & Fructose g $100 \mathrm{~g}^{-1}$ & $<0.20$ & $0.20 \pm 0.03$ \\
\hline Starch g $100 \mathrm{~g}^{-1}$ & $47.91 \pm 0.05$ & $50.12 \pm 0.05$ & Sucrose g $100 \mathrm{~g}^{-1}$ & $1.62 \pm 0.29$ & $1.80 \pm 0.25$ \\
\hline$\sum \mathrm{EAA} \mathrm{g} \mathrm{kg}^{-1}$ & $51.40 \pm 0.39$ & $55.50 \pm 0.42$ & Maltose g $100 \mathrm{~g}^{-1}$ & $<0.20$ & $<0.20$ \\
\hline Total amino acids $\mathrm{g} \mathrm{kg}^{-1}$ & $184.50 \pm 1.93$ & $180.10 \pm 1.82$ & Lactose g $100 \mathrm{~g}^{-1}$ & $<0.20$ & $<0.20$ \\
\hline
\end{tabular}

Note. $\sum \mathrm{EAA}$ - the sum of essential amino acids; values are the mean of 3 samples and respective standard deviations.

Chemical composition of the extruded product was not affected by temperature - the difference was not significant $(p>0.05)$, it was not affected by milling rate $(p>0.05)$ either. Protein content varied from 19.98\% to $20.74 \%$ and did not differ significantly $(p>0.05)$ among the tested samples. The results of our experiment showed an insignificant decrease $(p>0.05)$ in protein and $\beta$-glucans content in comparison with the untreated samples as well as an insignificant increase of starch content in the samples of the extruded products. Djurle et al. (2016) investigated milling and extrusion effects on dietary fibre and starch content of six barley cultivars and concluded that extrusion decreased the content of mixedlinkage (1-3)- and (1-4)- $\beta$-D-glucan but increased glucan extractability. The starch content was found to be higher in the extruded product than in untreated grains.

The impact of different temperatures of extrusion on the chemical composition and structure of the tested samples was determined. The structure was denser and less porous if extruded at lower temperatures. Higher temperatures improved the structure traits - crispier product was obtained. It could be due to the greater evaporation of water and more porous structure.

The evaluation of obtained results shows that different flour grinding grades did not affect the chemical composition of the extruded product significantly $(p>0.05)$. However, it should be noted that finer ground flour was difficult to mix with water, because moisture distributed unevenly. Finer ground flour also had lower content of $\beta$-glucans in comparison with medium and coarse ground flour.

The results of protein and starch content summarized in Table 3 are in line with other studies on the extrusion of the faba beans and peas - protein and starch are not lost in the extrusion process. The protein content in

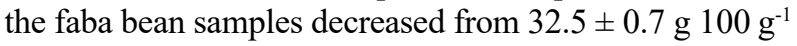

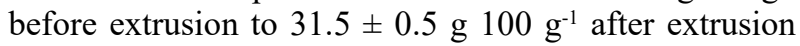
(Strauta, Muižniece-Brasava, 2016) or increased from $232.2 \pm 2.0 \mathrm{~g} \mathrm{~kg}^{-1}$ before extrusion to $272.0 \pm 3.1 \mathrm{~g} \mathrm{~kg}^{-1}$ after extrusion (Kudlinskienè et al., 2020). The effect of extrusion on $\beta$-glucans content not well documented in literature, but the results of our experiment showed that it was not significantly $(p>0.05)$ affected by the extrusion.

The total essential amino acids amount increased, even though protein and total amino acids contents slightly decreased. Comparison of amino acids profile of hulless barley 'Kornelija' untreated flour and extruded product is provided in Figure 1.

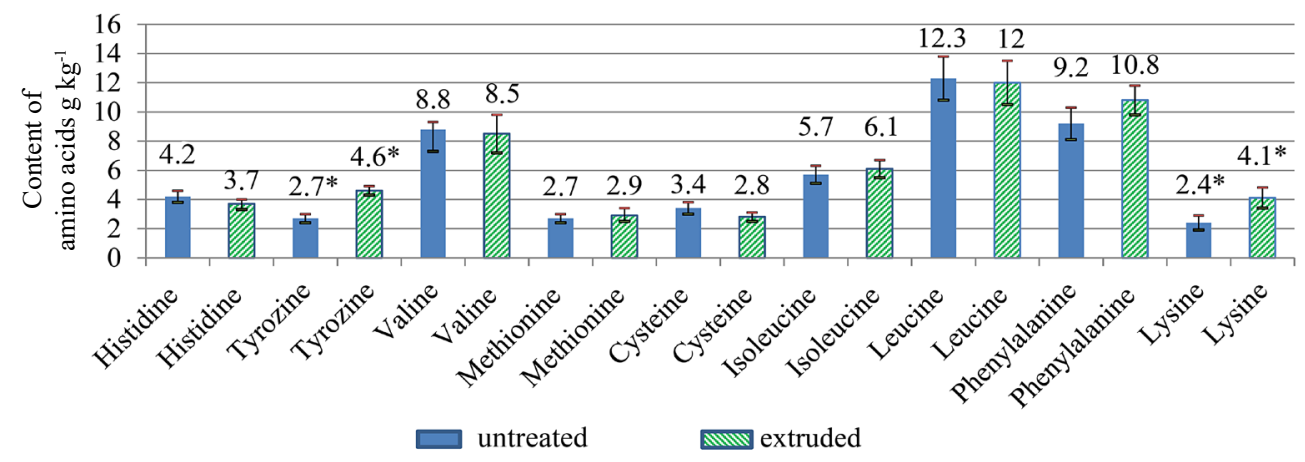

Note. ${ }^{*}-p<0.05$; values are the mean of 3 samples and respective standard deviations.

Figure 1. The comparison of essential amino acids profile of untreated and extruded hulless barley 'Kornelija' samples 
In our experiment, the comparison of essential amino acids content showed that the amount of tyrozine $4.6 \mathrm{~g} \mathrm{~kg}^{-1}$ and lysine $4.1 \mathrm{~g} \mathrm{~kg}^{-1}$ was significantly higher $(p<$ 0.05 ) in the extruded products in comparison with untreated samples -2.7 and $2.4 \mathrm{~g} \mathrm{~kg}^{-1}$, respectively, but the amount of phenylalanine increased insignificantly $(p>0.05)$ - from $9.2 \mathrm{~g} \mathrm{~kg}^{-1}$ in the untreated samples to $10.8 \mathrm{~g} \mathrm{~kg}^{-1}$ in the extruded products . Kudlinskiene et al. (2020) reported that in the case of beans, the extrusion decreased the amount of lysine from 16.1 (untreated) to $15.1 \mathrm{~g} \mathrm{~kg}^{-1}$ (extruded) and significantly decreased the amount of histidine from
$12.3 \mathrm{~g} \mathrm{~kg}^{-1}$ (untreated) to $9.8 \mathrm{~g} \mathrm{~kg}^{-1}$ (extruded). The study used one screw vertical extruder, and internal temperature of extrusion was $135-155^{\circ} \mathrm{C}$.

Nutrition value and texture quality of pasta. Evaluation of different proportions of wheat and barley flour showed that optimal ratio is $20 \%$ hulless barley and $80 \%$ wheat flour. Replacing more than $20 \%$ of wheat with hulless barley flour makes the dough crumbly and difficult to form. Comparison of doughs with different proportion of wheat and barley flour is shown in Figure 2.
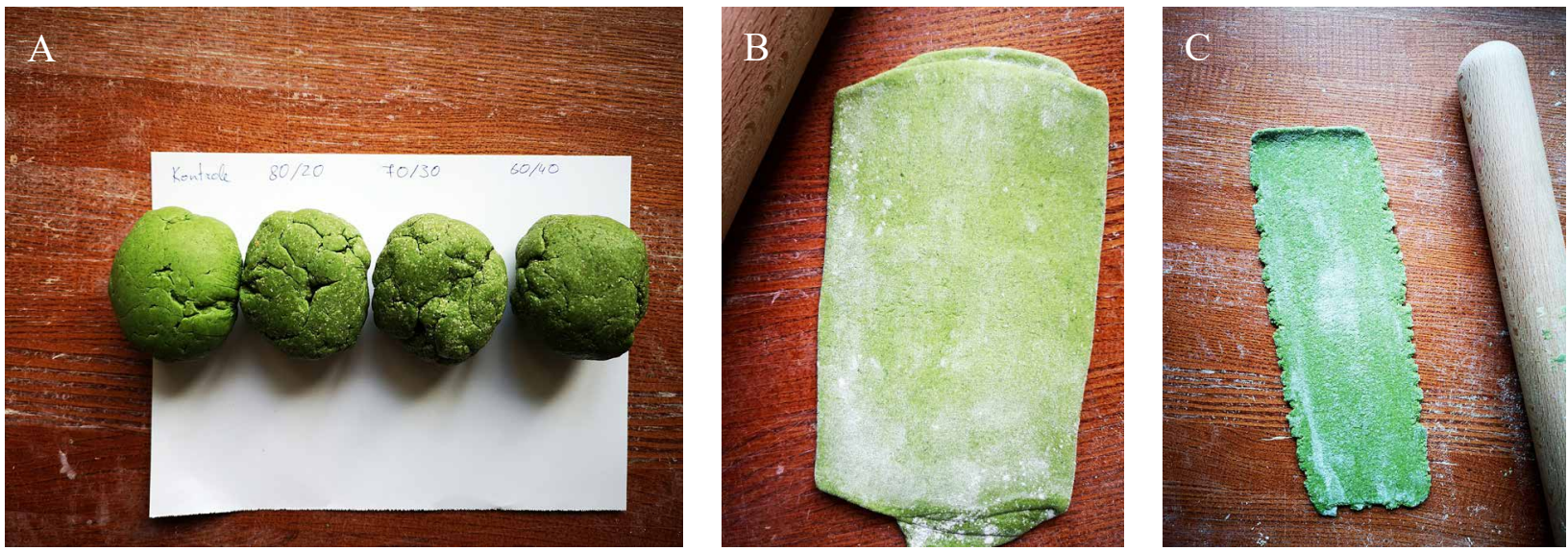

Figure 2. The comparison of colour and dough texture of pasta samples: $80 \mathrm{~W} / 40$ puree (control), $80 \mathrm{~W} / 20 \mathrm{~K}$, $70 \mathrm{~W} / 30 \mathrm{~K}$ and $60 \mathrm{~W} / 40 \mathrm{~K}$ (A), rolled doughs of $80 \mathrm{~W} / 40$ puree (control) (B) and $70 \mathrm{~W} / 30 \mathrm{~K}$ (C)

Grainy texture of dough was observed already at the lowest added amount of hulless barley flour and increased with increased amount of that. Dough samples with higher content of hulless barley flour were tighter and drier. Rolling process was affected by the grainy texture of the dough. More pronounced grainy texture led to cracking of the dough and more clippings occurred. Sticking of the dough to the oak surface was inversely proportional to the amount of hulless barley flour. When comparing the colour of the dough, it was observed that as the amount of added hulless barley flour increased, the colour of the samples became darker.

Study on pasta enriched with whole grain wheat, rye and hulless barley flour was made by Kalnina (2017). It was concluded that to obtain dough with good properties for pasta production, $20 \%$ of wheat flour type 405 could be replaced with whole rye and hulless barley grain 'Irbe' flour and with $50 \%$ of whole wheat grain flour. Evaluation of different proportions of wheat and barley flour in our experiment was similar, although it was expected that water absorption capacity of hulless barley 'Kornelija' flour would be better than for 'Irbe' and would allow producers to increase the hulless barley proportion in the pasta.

Comparison of chemical composition and nutritional value of pasta samples is summarized in Table 4 . The results show that by replacing $20 \%$ of wheat flour with hulless barley flour the content of protein increased by $1.15 \%$, and that of total dietary fibre - by $1.35 \%$. The content of soluble fibre $\beta$-glucans, which are beneficial for the intestinal flora, was found to be four times higher in the samples enriched with hulless barley flour.

In our experiment, essential amino acids content of pasta samples was determined, which allowed us to conclude that with $100 \mathrm{~g}$ of pasta it is possible to receive
Table 4. The chemical composition and nutritional value of wheat flour pasta samples

\begin{tabular}{|c|c|c|}
\hline Nutrients & $\begin{array}{c}80 \mathrm{~W} / 40 \mathrm{~g} \text { puree } \\
\text { (control) }\end{array}$ & $80 \mathrm{~W} / 20 \mathrm{~K}$ \\
\hline Protein \% & $14.22 \pm 0.22$ & $15.37 \pm 0.29$ \\
\hline Fat $\%$ & $0.28 \pm 0.12$ & $0.40 \pm 0.15$ \\
\hline Starch \% & $66.24 \pm 1.22$ & $63.57 \pm 0.90$ \\
\hline$\beta$-glucans \% & $0.27 \pm 0.03$ & $1.15 \pm 0.09$ \\
\hline Total dietary fibre & $3.15 \pm 0.80$ & $4.50 \pm 1.00$ \\
\hline \multicolumn{3}{|c|}{ Nutrition value } \\
\hline $\mathrm{kJ}$ & $1403 \pm 22$ & $1393 \pm 25$ \\
\hline kcal & $331 \pm 10$ & $329 \pm 6$ \\
\hline
\end{tabular}

Note. Values are the mean of 3 samples and respective standard deviations.

$15.3 \mathrm{~g}$ of protein, including $7.3 \mathrm{~g}$ of essential amino acids. The content of essential amino acids is shown in Figure 3.

Nutrition value and texture quality of semifinished mixes. Evaluation of different proportions of extruded pea flakes and hulless barley flour showed that optimal ratio from the point of view of density and structure are for the mixed samples $80 \mathrm{P} / 20 \mathrm{~K}$ and 70 $\mathrm{P} / 30 \mathrm{~K}$. Replacing more than $30 \%$ of pea flakes with hulless barley flour makes the scones less flexible and more grainy. Comparison of structure of fried scones from all mixed samples is shown in Figure 4.

Visual assessment of the fried scones shows that the colour became brighter, and the coarsest particles of flour increased with increased flour content. Scones of the sample $80 \mathrm{P} / 20 \mathrm{~K}$ were noticeably more porous; scones of the sample $50 \mathrm{P} / 50 \mathrm{~K}$ had denser structure, more like that of bread and a longer baking time: 10 versus $8 \mathrm{~min}$ for the samples $80 \mathrm{P} / 20 \mathrm{~K}$ and $70 \mathrm{P} / 30 \mathrm{~K}$. 


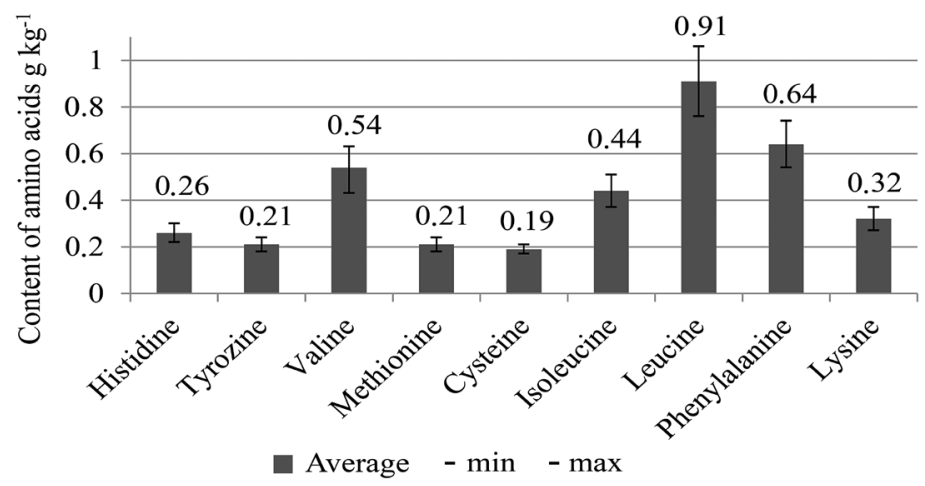

Note. Values are the mean of 3 samples and respective standard deviations.

Figure 3. The content of essential amino acids of wheat flour pasta $(80 \mathrm{~W} / 20 \mathrm{~K})$ samples

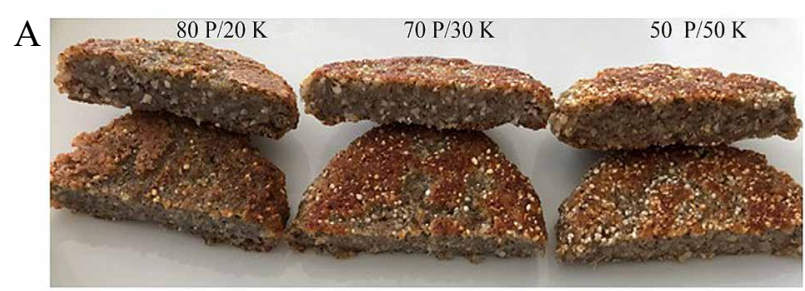

B

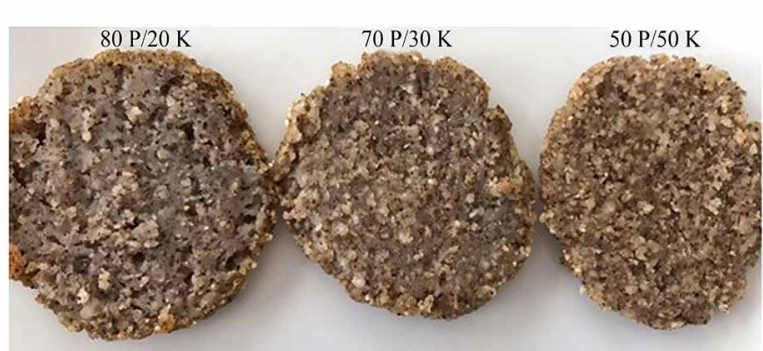

Figure 4. The comparison of colour and structure of fried scones containing hulless barley 'Kornelija' flour at different proportions: the height (A) and the cross section (B) of mixed samples

Evaluation of taste. The taste of samples 80 $\mathrm{P} / 20 \mathrm{~K}$ and $70 \mathrm{P} / 30 \mathrm{~K}$ was similar, but unlike peas scones the presence of the flour was felt. Sample $50 \mathrm{P} / 50 \mathrm{~K}$ had a strongly felt bitter barley flour taste and aftertaste. Chemical composition and nutrition value of semifinished products are shown in Table 5.

Comparison of the chemical composition allowed to conclude that protein content of mixes was higher than that in the control samples. With the addition of hulless barley flour, for example, $30 \%$ of total amount (70

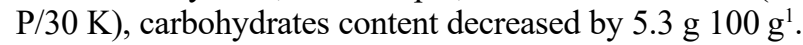
Dietary fibre content $(11.1 \%)$ determined in the sample $70 \mathrm{P} / 30 \mathrm{~K}$ did not differ significantly in comparison with the control sample $-8.4 \%(p>0.05)$, but it was enriched with soluble fibre $\beta$-glucans of barley.
Table 5. The chemical composition and nutritional value of extruded pea flakes and semi-finished mixes containing hulless barley 'Kornelija' flour at different proportions

\begin{tabular}{|c|c|c|c|c|}
\hline Nutrients & $\begin{array}{c}\text { Extruded } \\
\text { pea flakes } \\
\text { (control) }\end{array}$ & $80 \mathrm{P} / 20 \mathrm{~K}$ & $70 \mathrm{P} / 30 \mathrm{~K}$ & $50 \mathrm{P} / 50 \mathrm{~K}$ \\
\hline Protein \% & $17.1 \pm 0.2$ & $17.9 \pm 0.1$ & $18.2 \pm 0.2$ & $19.0 \pm 0.2$ \\
\hline Fat $\%$ & $1.5 \pm 0.1$ & $1.6 \pm 0.1$ & $1.7 \pm 0.1$ & $1.8 \pm 0.2$ \\
\hline Carbohydrate $\%$ & $67.3 \pm 1.0$ & $63.8 \pm 1.0$ & $62.0 \pm 0.9$ & $58.5 \pm 0.9$ \\
\hline Dietary fibre $\%$ & $8.4 \pm 0.8$ & $10.2 \pm 0.9$ & $11.1 \pm 1.0$ & $12.9 \pm 1.0$ \\
\hline$\beta$-glucans \% & - & $1.5 \pm 0.1$ & $2.0 \pm 0.1$ & $3.2 \pm 0.1$ \\
\hline \multicolumn{5}{|l|}{ Nutrition value } \\
\hline $\mathrm{kJ}$ & 1565 & 1529 & 1515 & 1487 \\
\hline $\mathrm{kcal}$ & 370 & 362 & 358 & 352 \\
\hline
\end{tabular}

Note. Values are the mean of 3 samples and respective standard deviations.

In general, this study confirmed that hulless barley 'Kornelija' flour can be used as a raw material in wholegrain products, breakfast cereals, biscuits and snacks, which are extruded without losing nutrients. In the production of functional food products, the hulless barley grains may not only replace the currently used raw materials but also become a source of inspiration for the development of new food products and the implementation thereof in production (Fig. 5).

Hulless barley 'Kornelija' grains are very wellsuited for increasing the nutritional value of traditional whole grain products (pearl, flour, bread and pastry) as well as for producing specific functional and niche foods as protein bars, breakfast cereal or food additives. Various end use possibilities give large opportunities for further studies on the use of hulless barley grains to improve the nutrition value of different food products.
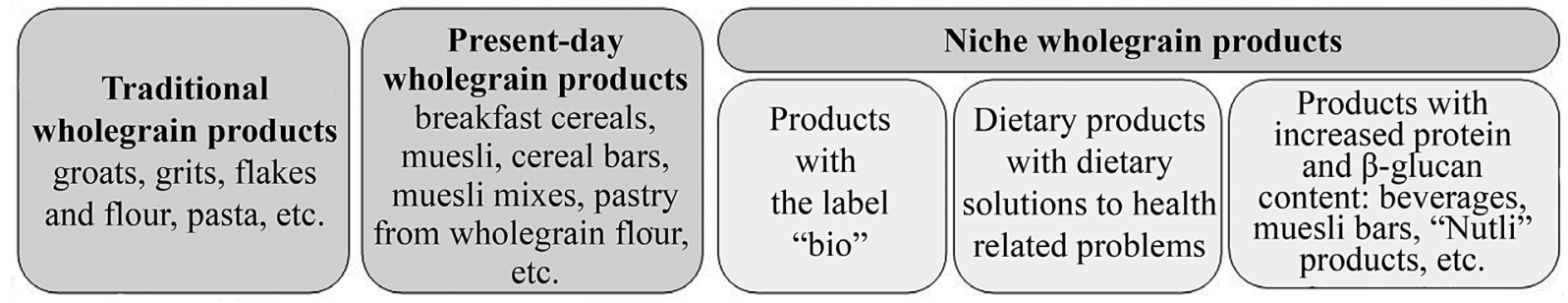

Figure 5. Opportunities for the hulless barley 'Kornelija' grains or flour to be used in the food industry 


\section{Conclusions}

1. The extrusion process had a minor effect on the protein and $\beta$-glucans content of the extruded product of hulless barley flour. While total essential amino acids content of the extruded samples were determined higher $\left(55.5 \mathrm{~g} \mathrm{~kg}^{-1}\right)$ in comparison with the untreated samples $\left(51.4 \mathrm{~g} \mathrm{~kg}^{-1}\right)$ with significantly higher content of tyrozine and lysine in the extruded samples.

2. By replacing $20 \%$ of wheat flour with the flour of hulless barley cultivar 'Kornelija' to improve the nutritional value of pasta, the content of protein and dietary fibre significantly increased. The content of soluble fibre $\beta$-glucans was also four times higher in the products enriched with hulless barley flour. Dough samples with a higher content of hulless barley flour were tighter and drier. Rolling process was affected by grainy texture of the dough. More pronounced grainy texture led to cracking of the dough and more clippings occurred.

3. A combination of extruded pea flakes with hulless barley flour to improve the nutritional value of the product (fried scones) allowed an increase in the content of protein and dietary fibre. The optimal proportion of the product was determined at sample $70 \mathrm{P} / 30 \mathrm{~K}$ ( $70 \mathrm{~g}$ of extruded pea flakes and $30 \mathrm{~g}$ of hulless barley flour).

\section{Acknowledgments}

The study on barley technological traits has received the financial support within the project "The hulless barley variety 'Kornelija' - high-quality wholegrain raw material for developing niche and functional products" (within the scope of project No. KC-PI-2017/43).

Extrusion of hulless barley flour was carried out at the laboratories of the Faculty of Food Technology of the Latvia University of Life Sciences and Technologies. The study of pasta preparation of different proportions of wheat and barley flour was supported by ColorPasta Ltd.

The study on peas semi-finished products was conducted by Milzu! Ltd. under the support from the European Regional Development Fund for the general contract No. 1.2.1.1/18/A/002 between the Latvian Food Industry Competence Centre and the Central Finance and Contracting Agency of Latvia.

Received 30042020

Accepted 22102020

\section{References}

Alminger M., Eklund-Johnson C. 2008. Whole-grain cereal products based on a high-fibre barley or oat genotype lower post-prandial glucose and insulin responses in healthy humans. European Journal of Nutrition, 47: 294-300. https://doi.org/10.1007/s00394-008-0724-9

Ames N., Rhymer C., Rossnagel B., Therrien M., Ryland D., Dua S. 2006. Utilization of diverse hulless barley properties to maximize food product quality. Cereal Foods World, 51: 23-38. https://doi.org/10.1094/CFW-51-0023

Arendt E. K., Zannini E. 2013. Cereal grains for the food and beverage industries. Hughes S. (ed.). Barley. Woodhead Publishing. p. 155-200.

https://doi.org/10.1533/9780857098924.155
Baik B. K., Ullrich S. E. 2008. Barley for food: characteristics, improvement, and renewed interest. Journal of Cereal Science. 48: 233-242. https://doi.org/10.1016/j.jcs.2008.02.002

Bleidere M., Zute S., Jākobsone I. 2013. Characterisation of physical and biochemical traits of hulless spring barley grain in Latvian breeding program. Proceedings of the Latvian Academv of Science. Section B. 67 (4-5): 399404. https://doi.org/10.2478/prolas-2013-0065

Diaz D., Morlacchini M., Masoero F., Moschini M., Fusconi G., Piva G. 2006. Pea seeds (Pisum sativum), faba beans (Vicia faba var. minor) and lupin seeds (Lupinus albus var. multitalia) as protein sources in broiler diets: effect of extrusion on growth performance. Italian Journal of Animal Science, 5 (1): 45-53. https://doi.org/10.4081/ijas.2006.43

Díaz L. D., Fernández-Ruiz V., Cámara M. 2020. An international regulatory review of food health-related claims in functional food products labeling. Journal of Functional Foods. 68: 103896 https://doi.org/10.1016/j.jff.2020.103896

Djurle S., Adersson A. A. M., Andersson R. 2016. Milling and extrusion of six barley varieties, effects on dietary fibre and starch content and composition. Journal of Cereal Science, 72: 146-152. https://doí.org/10.1016/j.jcs.2016.09.017

Ehrenbergerova J., Vaculova K., Psota V., Havlova P., Serhantova V. 2003. Effects of cropping system and genotype on variability in important phytonutrients content of the barley grain for direct food use. Plant, Soil and Environment. 49 (10): 443-450. https://doi.org/10.17221/4155-PSE

Eurostat. 2020. Crop production in EU standard humidity. https:// appsso.eurostat.ec.europa.eu/nui/show.do?dataset=apro_ cpsh1\&lang=en

Grand View Research. 2020. Functional foods market size, share and trends analysis report by ingredient (carotenoids, prebiotics and probiotics, fatty acids, dietary fibers), by product, by application, and segment forecasts, 2019-2025. https://www.grandviewresearch.com/industry-analysis/ functional-food-market

Havrlentova M., Petrulakova Z., Burgarova A., Gago F., Hlinkova A., Sturdik E. 2011. Cereal $\beta$-glucans and their significance for preparation of funcional food - a review. Czech Journal of Food Sciences. 29 (1): 1-4. https://doi.org/10.17221/162/2009-CJFS

Jenkins A. L., Jenkins D. J. A., Zdravkovic U., Wursch P., Vuksan, V. 2002. Depression of the glycaemic index by high levels of beta-glucan fiber in two functional foods tested in type 2 diabetes. European Journal of Clinical Nutrition, 56: 622-628.

Kalnina S. 2017. Suitability of cereals cultivated in Latvia for whole - grain pasta production: doctoral dissertation. Latvia University of Life Sciences and Technologies, 96 p.

Kinner M., Nitschko S., Sommeregger J., Petrasch A., Linsberger-Martin G., Grausgruber H. 2011. Naked barley optimized recipe for pure barley bread with sufficient betaglucan according to the EFSA health claims. Journal of Cereal Science, 53 (2): 225-230. https://doi.org/10.1016/j.jcs.2011.01.001

Kudlinskienė I., Gružauskas R., Daukšienė A., Dovidaitienė G., Želvytė R., Monkevičienė I., Šližius E., Urbšienė D., Racevičiūtè-Stupelienè A., Ots M., Kass M., Žilinskas H., Stankevičius R. 2020. Effect of extrusion on the chemical composition of the faba beans and its influence on Lactation performance of dairv cows. Zemdirbvste-Agriculture, 107 (1): 87-94. https://doi.org/10.13080/z-a.2020.107.012

Martirosyan D. M., Singh J. 2015. A new definition of functional food by FFC: what makes a new definition unique? Functional Foods in Health and Disease, 5 (6):209-223. https://doi.org/10.31989/ffhd.v5i6.183

Meija L., Havensone G., Lejnieks A. 2019. Postprandial glycaemic and insulinaemic responses after consumption of activated wheat and triticale grain flakes. Journal of Nutrition and Metabolism. 2019: 1-7. https://doi.org/10.1155/2019/6594896 
Mitsou E. K., Panopoulou N., Turunen K., Spiliotis V., Kyriacou A., 2010. Prebiotic potential of barley derived $\beta$-glucan at low intake levels: a randomised, doubleblinded, placebo-controlled clinical study. Food Research International. 43: 1086-1092.

https://doi.org/10.1016/j.foodres.2010.01.020

New Nutrition Business. 2019. 10 key trends in food, nutrition and health 2020. https://www.new-nutrition.com/ keytrend?id $=135$

Newman R. K., Newman C. W. 2008. Barley for food and health: science, technology, and products. Barley: genetics and nutrient composition. John Wiley and Sons, p. 56-94.

Nikmaram N., Leong S. Y., Koubaa M., Zhu Z., Barba F. J, Greiner R., Oey I., Roohinejad S. 2017. Effect of extrusion on the anti-nutritional factors of food products: an overview. Food Control, 79: 62-73.

Nunes R., Silva V. L., Kasemodel M. G., Polizer Y. J., Saes M. S., Fávaro-Trindade C. S. 2020. Assessing global changing food patterns: a country-level analysis on the consumption of food products with health and wellness claims. Journal of Cleaner Production, 264: 121613.

Rieder A. Holtekj Ølen A. K., Sahlstrom S., Moldestad A. 2012. Effect of barley and oat flour types and sourdoughs on dough rheology and bread quality of composite wheat bread. Journal of Cereal Science, 55: 44-52.

Ruggiero E., Bonaccio M., Di Castelnuovo A., Bonanni A., Costanzo S., Persichillo M., Bracone F., Cerletti C., Donati M.B., de Gaetano G., Iacoviello L. on behalf of the INHES Study Investigators. 2019. Consumption of whole grain food and its determinants in a general Italian population: results from the INHES study. Nutrition, Metabolism and Cardiovascular Diseases. 29 (6): 611-620. https://doi.org/10.1016/j.numecd.2019.03.001
Sterna V., Zute S., Jansone I., Kantane I. 2017. Chemical composition of covered and naked spring barley varieties and their potential for food production. Polish Journal of Food and Nutrition Sciences. 67 (2): 151-155. https://doi.org/10.1515/pjfns-2016-0019

Sterna V., Kunkulberga D., Straumite E., Bernande K. 2019. Naked barley influence on wheat bread quality. FoodBalt 2019: proceedings of $13^{\text {th }}$ Baltic conference on food science and technology Food. Nutrition. Well-Being. Jelgava, Latvia, p. 98-102. https://doi.org/10.22616/FoodBalt.2019.016

Strauta L., Muižniece-Brasava S. 2016. The characteristic of extruded faba beans (Vicia faba L.). Rural Sustainability Research. 36 (331): 42-48. https://doi.org/10.1515/plua-2016-0013

Sturite I., Kronberga A., Strazdina V., Kokare A., Aassveen M., Kari A., Olsen B. 2019. Adaptability of hull-less barley varieties to different cropping systems and climatic conditions. Acta Agriculture Scandinavica, Section B: Soil and Plant Science. 69 (1): 1-11.

https://doi.org/10.1080/09064710.2018.1481995

Tamm Y., Jansone I., Zute S., Jakobsone I. 2015. Genetic and environmental variation of barley characteristics and the potential of local origin genotypes for food production. Proceedings of the Latvian Academy of Science, Section B. 69 (4): 163-169. https://doi.org/10.1515/prolas-2015-0024

Vicentini A., Liberatore L., Mastrocola D. 2016. Functional foods: trends and development of the global market. Italian Journal of Food Science, 28 (2): 338-351.

\title{
Produktų mitybinès vertès gerinimas veislès 'Kornelija' belukščių miežių miltais
}

\author{
V. Sterna ${ }^{1}$, M. Bleidere ${ }^{1}$, M. Sabovics ${ }^{2}$, A. Auzins ${ }^{1}$, I. Leimane ${ }^{1}$, A. Krievina ${ }^{1}$ \\ 'Žemès ūkio išteklių ir ekonomikos institutas „Dižzemes“, Latvija \\ ${ }^{2}$ Latvijos gyvybės mokslų ir technologijų universitetas
}

\section{Santrauka}

Belukščių miežių panaudojimo ịvairiems tikslams potencialas sulaukia vis daugiau dèmesio, nes dẻl sudedamųjų dalių naudos sveikatai šie grūdai yra puiki funkcinio maisto žaliava. Palyginti su lukštingais, belukščiai miežiai yra ekonomiškai naudingi maisto pramonei, taip pat suteikia galimybę ūkininkams auginti ịvairesnių javų. Tai leidžia pagerinti turimų grūdų produktų mitybinę vertę ir įvertinti naujus produktus. Nepaisant šių pranašumų, belukščiai miežiai nèra plačiai naudojami Europos šalių maisto pramonèje.

Tyrimo tikslas - taikant ekstrudavimą ir belukščių miežių miltų dedant į makaronus bei ekstruduotus žirnių dribsnių mišinius, nustatyti didesnès mitybinès vertès produktų, kurių žaliavoje yra veislès 'Kornelija' belukščių miežių grūdų, gamybos galimybes. Tyrimo duomenimis, ekstrudavimas neturẻjo didelès įtakos belukščių miežiu cheminei sudèčiai (baltymų ir $\beta$-gliukanų kiekiui), o pagrindinių aminorūgščių suma buvo nustatyta didesnè $\left(55,5 \mathrm{~g} \mathrm{~kg}^{-1}\right)$, palyginti su neapdorotais mėginiais $\left(51,4 \mathrm{~g} \mathrm{~kg}^{-1}\right)$ su žymiai didesniu kiekiu tirozino ir lizino. Taip pat nustatyta, kad, siekiant pagerinti makaronų mitybinę vertę ir $20 \%$ kvietinių miltų pakeitus belukščių miežių miltais, padidejjo baltymų ir maistinių skaidulų kiekis. Ekstruduotų žirnių dribsnių ir belukščių miežių miltų derinys taip pat pagerino žirnių ir miežių mišinių pusgaminių mitybinę vertę dèl didesnio baltymų ir maistinių skaidulų kiekio.

Reikšminiai žodžiai: ekstrudavimas, funkcinis maistas, belukščiai miežiai, mitybinė vertè, makaronai. 